\title{
高強度コンクリートの諸性状に関する研究 \\ PROPERTIES OF HIGH STRENGTH CONCRETE
}

\author{
近 藤 時 夫* \\ By Tokio KONDO
}

\section{1. まえがき}

この数年来, 高強度コンクリートーの関心が高まって おり, 新たに開発された高性能減水㓮を用いた高強度コ ンクリートの建設工事への適用がなされつつある.

わが国に打ける減水剤にはきわめて多くの種類がある が，高強度コンクリートを造るのに適した減水剤はこれ らすべてが適しているとはいい難く, 減水性, 空気連行 性, 硬化遅延作用, 塩化物含有の有無などからみて, 多 環アロマスルフォン酸塩系減水鼡およびナフタリンスル フォン酸塩のホルマリン縮合物系減水剤が高強度コンク リートの製造に適していると考えられる.

これら高性能減水片あるいはこれを用いた高強度コン クリートの諸性状については他にも報告がなされてお り，そのいくつかを参考文献に揭げた ${ }^{1) ~ 6) . ~}$

本研究は, 高強度コンクリートの諸性状をさらに明ら かにする目的で, 高性能減水剂として主として多環ア口 マスルフォン酸塩系減水剤を使用し，骨材として天然骨 材および（または）高強度化に有效と考えられるセメン トクリンカーを使用した高強度コンクリートならびに強 度低下の欠点はあるが施工性, 耐久性の向上への検討の ために空気連行を行った高強度コンクリートについて, 各種養生条件の下での各種強度, 变形に関する諸性質お よび而久性ならびに温度, 高性能減水剤添加方法が施工 性に及ぼす影響について試験を行って, 高強度コンクリ 一トによる構造物の設計施工にあたっての問題点を検討 した結果について論ずるものである.

\section{2. 試 験 概 要}

\section{(1) 実験項目}

実験に用いたコンクリート種別は，骨材の種別，目標

* 正会員 工愽 日本鉄道建設公団設計室長
表-1 コンクリートの配合種別

\begin{tabular}{|c|c|c|c|c|}
\hline $\begin{array}{ll}\text { 配 畣 } \\
\text { 種 別 }\end{array}$ & 骨 材 & 粗，筩材 & 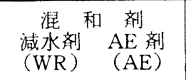 & $\begin{array}{l}\text { 是 標 } \\
\text { 空父晿 } \\
\text { (\%) } \\
\text { (\%) }\end{array}$ \\
\hline No. 1 & 川 & 石 & WR $(C \times 0.75 \%)$ & - \\
\hline No. 2 & $"$ & クリンカー & WR $(C \times 0.75 \%)$ & - \\
\hline No. 3 & クリンカー+川砂 & " & WR $(C \times 0.75 \%)$ & - \\
\hline No. 4 & 川 & 砕 & $\begin{array}{l}\mathrm{WR}(C \times 0.75 \%)+ \\
\mathrm{AE}(C \times 0.003 \%)\end{array}$ & 2.5 \\
\hline No. 5 & " & " & $\begin{array}{l}\text { WR }(C \times 0.75 \%)+ \\
\mathrm{AE}(C \times 0.005 \%)\end{array}$ & 4.0 \\
\hline
\end{tabular}

空気連行量によって, 表一1 に示す 5 種類である.

硬化した高強度コンクリートの諸性状に関する実験で は, 圧縮強度, 引張強度, 曲げ強度, 静および動弾性係 数の 4 種類の養生条件の下での材令 1 年までの諸特性に ついての試験, ポアソン比の標準養生の下での材令 1 年 までの試験， 2 種類の養生条件の下で製造した 2 種類の 高強度コンクリートの乾燥収縮, クリープの 3 種類の環 境湿度下における材令約 250 日にいたるまでの変形に ついての試験， 4 種類のコンクリート種別について 2 種 類の養生条件下に㧍ける高強度コンクリートの凍結融解 に対する抵抗性の試験を行った。

高強度コンクリートのワーカビリチーに関する実験で は，天然骨材を使用した空気連行と非連行のコンクリー トについて, 温度がワーカビリチーに及ぼす影響などに ついての試験および高性能減水剤の添加方法の差がワー カビリチーに及ぼす影響などについての試験を行った。

\section{（2）目標品質}

本試験で目標とした高強度コンクリートの品質は, 施 工性を考慮して目標スランプを $10 \sim 13 \mathrm{~cm}$ とし，まず 水セメント比を変化させて行った配合選定試験をもとと して, 現時点で実用可能と考えられる設計基準強度の目 標を $\sigma_{c k}=800 \mathrm{~kg} / \mathrm{cm}^{2}$ （材令 28 日）として配合強度を $\sigma_{r}=850 \mathrm{~kg} / \mathrm{cm}^{2}$ とした.なお, 空気連行コンクリートに 対しては, 同一目標強度とすると笊位セメント量が過大 となるため, 配合強度を $800 \mathrm{~kg} / \mathrm{cm}^{2}$ とした。 
表一2 セメントの物理試験結果

\begin{tabular}{|c|c|c|c|c|c|c|c|c|c|c|c|c|c|c|c|}
\hline \multirow{2}{*}{ 種 } & \multirow{2}{*}{ 類 } & \multirow{2}{*}{ 比重 } & \multirow{2}{*}{ 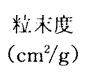 } & \multicolumn{2}{|c|}{ 凝結時間（時：分） } & \multirow{2}{*}{ 安定性 } & \multirow{2}{*}{$\begin{array}{l}\text { フロ } \\
(\mathrm{mm})\end{array}$} & \multicolumn{4}{|c|}{ 曲げ強度 $\left(\mathrm{kg} / \mathrm{cm}^{2}\right)$} & \multicolumn{4}{|c|}{ 任縮強度 $\left(\mathrm{kg} / \mathrm{cm}^{2}\right)$} \\
\hline & & & & 始 発 & 終 絬 & & & $1 \mathrm{\theta}$ & 3 日 & 7 日 & 2811 & 1 日 & 3 日 & 7 日 & 28 日 \\
\hline \multirow{3}{*}{\multicolumn{2}{|c|}{$\begin{array}{l}\text { U休社早強 } \\
\text { 小野田社早強 } \\
\text { 小野的社普通 }\end{array}$}} & 3.14 & 3960 & $3: 15$ & $4: 49$ & 良 & 217 & 33.0 & 54.5 & 70.4 & 79.4 & 129 & 280 & 388 & 481 \\
\hline & & 3.12 & 4030 & $2: 13$ & $3: 08$ & 良 & 228 & 33.2 & 49.6 & 64.1 & 76.8 & 121 & 221 & 334 & 433 \\
\hline & & 3.16 & 3030 & $2: 54$ & $3: 48$ & 良 & 251 & - & 34.5 & 53.4 & 71.5 & - & 142 & 256 & 441 \\
\hline
\end{tabular}

表-3 細粗骨材の物理試験結果

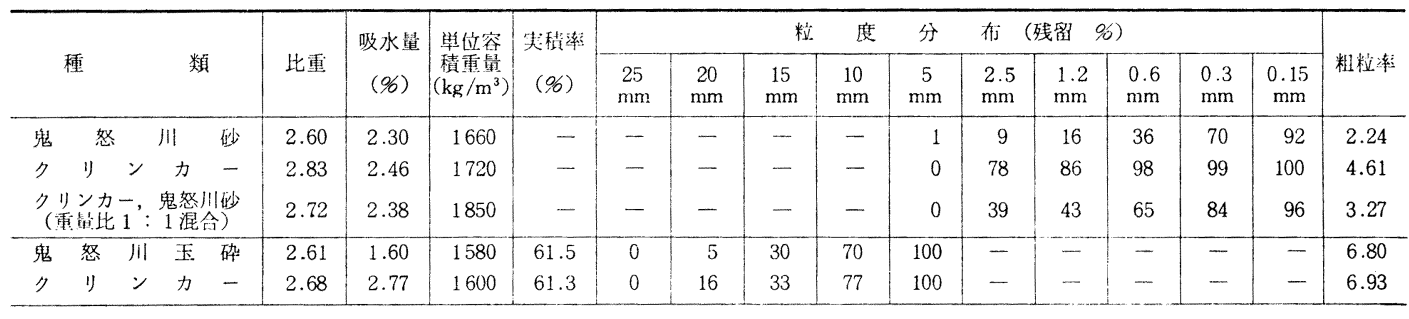

\section{(3) 使用材料}

a) セメント

セメントは早強ポルトランドセメント (日本社製) を 用いたが，ワーカビリチーに関する実験には早強および 普通ポルトランドセメント（ともに小野田社製）を使用 した. セメントの物理試験の結果を 表一2 に示す.

\section{b）骨材}

細粗骨材には, 天然骨材として鬼怒川産の川砂および 玉石枠石を，一部試験には反忘性骨材を用いた高強度化 のために人工骨材である早強セメントクリンカー（小野 田社藤原工場製）を使用した。

クリンカー細骨材は細粒のものが得られず, FM= 4.61 で標準粒度範囲から大きく外れるため, 人工骨材 の細骨材としてクリンカー (5 mm 以下) と鬼怒川産川 砂（1.2 $\mathrm{mm}$ 以下）とを重量比で等量混合したものを使 用した.

これら細粗骨材の物理試験結果を 表一3 に示す.

c) 混和 剂

高強度コンクリート用減水剂として, 特に断らない限 り多環アロマスルフォン酸塩系の高性能減水剂（以下 A 剂という）を使用した. 空気連行高強度コンクリートに 対しては,さらにアニオン系の $\mathrm{AE}$ 剂を使用した.

\section{（4）コンクリートの配合}

単位セメント量を $500,600,700 \mathrm{~kg}$ (クリンカー粗骨 材使用の場合には $350,400 \mathrm{~kg}$ を追加）として水セメン 卜比を変化させて行った配合選定試験の結果に基つきき, 示方配合を 表一4 に示す 5 種類に定め, 試験項目によ って全種類または数種類を選択した.

\section{（5）養生方法}

槷生方法の差による影響を検討するために選定した養
表-4 コンクリートの配合

\begin{tabular}{|c|c|c|c|c|c|c|c|c|}
\hline \multirow{2}{*}{ 配畣 } & \multirow{2}{*}{$\begin{array}{l}\text { 水セx } \\
\text { v } \begin{array}{c}\text { 比 } \\
(\%)\end{array}\end{array}$} & \multirow{2}{*}{$\begin{array}{l}\text { 細骨 } \\
\text { 染率 } \\
(\%)\end{array}$} & \multicolumn{4}{|c|}{ 策位量 $\left(\mathrm{kg} / \mathrm{m}^{3}\right)$} & \multirow{2}{*}{$\begin{array}{c}\text { スランプ } \\
(\mathrm{cm})\end{array}$} & \multirow{2}{*}{$\begin{array}{c}\text { 空気量 } \\
\text { (\%) }\end{array}$} \\
\hline & & & $\begin{array}{l}\text { セx } \\
\text { ント }\end{array}$ & 水 & 細管材 & 粗能材 & & \\
\hline No. 1 & 33.4 & 31 & 530 & 177 & 515 & 1151 & 13.7 & 1.4 \\
\hline No.2 & 37.5 & 35 & 400 & 150 & 662 & 1214 & 13.3 & 0.5 \\
\hline No. 3 & 39.7 & 47 & 360 & 143 & 930 & 1033 & 9.9 & 0.8 \\
\hline No. 4 & 30.9 & 28 & 580 & 179 & 455 & 1175 & 11.0 & 2.6 \\
\hline No. 5 & 30.0 & 25 & 630 & 189 & 371 & 1117 & 11.0 & 3.7 \\
\hline
\end{tabular}

生条件は, 次の 4 種類である.

(1) 標準養生 : 温度 $21^{\circ} \mathrm{C}$, 湿度 $100 \%$ の恒温霧室中 養生

(2) 気中養生 : 温度 $21^{\circ} \mathrm{C}$, 湿度 $80 \%$ の恒温恒湿室中 養生

(3) 蒸気養生 : 型わく打込み後 2 時間経過してから蒸 気養生を開始し, 2.5 時間で $75^{\circ} \mathrm{C}$ まで昇温して 5 時間保持したのち徐冷し, 脱型後は気中養生

(4) オートクレーブ養生 : 蒸気養生後 1 日経過してか ら,オートクレーブ養生窯内で 2 時間で $180^{\circ} \mathrm{C}$ に昇 温し 5 時間保持したのち徐冷し, その後は気中養生 これら 4 種類の養生条件を試験項目によって全種類ま たは数種類を選択した。

\section{3. 硬化した高強度コンクリートの諸性状}

\section{（1）配合選定試験}

目標圧縮強度 $\sigma_{r}=850 \mathrm{~kg} / \mathrm{cm}^{2}$ を得る目的で単位セメ ント量を変化して配合選定試験を行った。その結果得ら れた材令 7 日，21 日および 28 日における圧縮強度とセ メント水比との関係は, 図一1 のとおりである.

これによれば, 圧縮強度とセメント水比との関係は一 部を除いてほぼ直線と近似すると考えられ，Abramsの 水セメント比説 ${ }^{7)}$ がこの種の高強度コンクリートにも成 


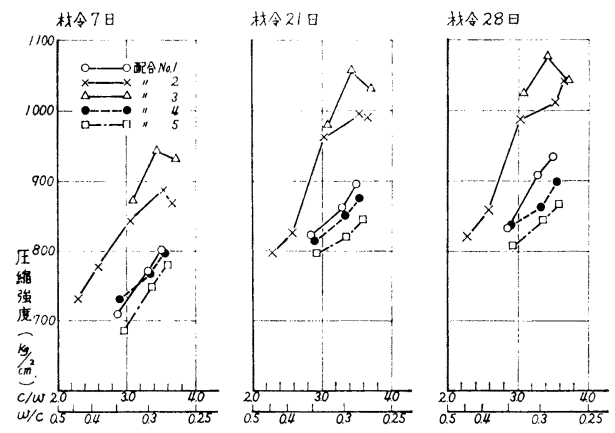

図一1 圧縮強度とセメント水比との関係
り立つことが分かる。

また，クリンカー骨材使用コンクリートの圧縮強度は 同一七メント水比の天然骨材使用のものより約 $100 \mathrm{~kg} /$ $\mathrm{cm}^{2}$ 大で, 本試験では材令 28 日において最大 $1077 \mathrm{~kg} /$ $\mathrm{cm}^{2}$ が得られたが, クリンカー骨材には Ansatz（焼成 窯付着物）が混在してダスチングにより体積膨張してコ ンクリートを内部から破壊することがあり，これがクリ ンカー骨材使用上のひとつの問題点である.

\section{（2）各種強度}

表一1 に示す 5 種類の配合種別について 4 種類の養生 を行ったコンクリートの材令 1 年までの圧縮強度および

表一5 圧 縮 強 度

\begin{tabular}{|c|c|c|c|c|c|c|c|}
\hline \multirow{2}{*}{ 配合㮔別 } & \multirow{2}{*}{ 等位: 条俳 } & \multicolumn{3}{|c|}{ 生 } & \multicolumn{3}{|c|}{$\left(\mathrm{kg} / \mathrm{cm}^{2}\right)$} \\
\hline & & $1 \quad \mathrm{~B}$ & 3 日 & 7 日 & 28 日 & 180 日 & 365 日 \\
\hline \multirow{4}{*}{ No. 1} & & $493(100)[57]$ & $655[76]$ & $738(100)[85]$ & $864(100)[100]$ & $994(100)[115]$ & $1001(100)[116]$ \\
\hline & 父元 & - & - & $694(94)[81]$ & $857(99)[100]$ & $921(93)[107]$ & $936(94)[109]$ \\
\hline & 蒸 父i & $522(106)[68]$ & - & $713(97)[92]$ & $773(89)[100]$ & - & $889(89)[115]$ \\
\hline & オートクレーブ & $937(190)[107]$ & - & $893(121)[102]$ & $879(102)[100]$ & - & $899(90)[102]$ \\
\hline \multirow{4}{*}{ No. 2} & 標準 & $425(100)[46]$ & $685[74]$ & $802(100)[87]$ & $920(100)[100]$ & $1010(100)[110]$ & $1107(100)[120]$ \\
\hline & & - & - & $797(99)[90]$ & $886(96)[100]$ & $964(95)[109]$ & $1006(91)[114]$ \\
\hline & & $507(119)[67]$ & - & $652(81)[86]$ & $759(83)[100]$ & - & $852(77)[112]$ \\
\hline & オートクレーブ & $674(159)[87]$ & $\cdots$ & $665(83)[86]$ & $771(84)[100]$ & - & $785(71)[102]$ \\
\hline \multirow{2}{*}{ No. 3} & 梌 & $355 \quad[41]$ & $609[71]$ & $708(100)[83]$ & $856(100)[100]$ & $968(100)[113]$ & $1035(100)[121]$ \\
\hline & 公 & - & -- & $691(98)[91]$ & $763(89)[100]$ & $844(87)[111]$ & $880(85)[115]$ \\
\hline \multirow{4}{*}{ No. 4} & 榴 溲 & $525(100)[64]$ & $699[82]$ & $713(100)[88]$ & $814(100)[100]$ & $922(100)[113]$ & $959(100)[118]$ \\
\hline & 'xi & - & - & $708(99)[89]$ & $799(98)[100]$ & $866(94)[108]$ & $893(93)[112]$ \\
\hline & 筣 $\quad$ 'xi & $544(104)[68]$ & -- & $667(94)[84]$ & $798(98)[100]$ & - & $870(91)[109]$ \\
\hline & オートクレーブ & $977(186)[106]$ & - & $926(130)[101]$ & $920(113)[100]$ & - & $935(97)[102]$ \\
\hline \multirow{4}{*}{ No. 5} & 聚 準 & $525(100)[66]$ & $657[83]$ & $714(100)[90]$ & $794(100)[100]$ & $892(100)[112]$ & $958(100)[121]$ \\
\hline & 父i & - & - & $702(98)[91]$ & $768(97)[100]$ & $826(93)[108]$ & $854(89)[111]$ \\
\hline & 澵父保 & $543(103)[71]$ & - & $635(89)[83]$ & $765(96)[100]$ & - & $789(82)[103]$ \\
\hline & オートクレーブ & $753(143)[90]$ & - & $859(120)[102]$ & $841(106)[100]$ & - & $853(89)[101]$ \\
\hline
\end{tabular}

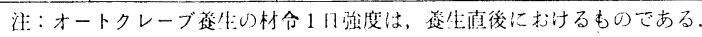

\section{表一6 引張強度および曲げ強度}

\begin{tabular}{|c|c|c|c|c|c|c|c|}
\hline \multirow{2}{*}{$\begin{array}{l}\text { 酧 合 } \\
\text { 種 別 }\end{array}$} & \multirow{2}{*}{ 養生条件 } & \multicolumn{3}{|c|}{ 引 張 強 度 $\left(\mathrm{kg} / \mathrm{cm}^{2}\right)$} & \multicolumn{3}{|c|}{ 曲 げ 強 度 $\left(\mathrm{kg} / \mathrm{cm}^{2}\right)$} \\
\hline & & 7 日 & 28 日 & 365 日 & 7 日 & 28 日 & 365 日 \\
\hline \multirow{4}{*}{ No. 1} & 標準 & $49.7(100)[93]$ & $53.4(100)[100]$ & $58.5(100)[110]$ & $80.2(100)[85]$ & $94.4(100)[100]$ & $110.9(100)[117]$ \\
\hline & 気 & $47.3(95)[96]$ & $49.4(93)[100]$ & $52.9(90)[107]$ & $71.5(89)[100]$ & $71.7(76)[100]$ & $84.2(76)[117]$ \\
\hline & & - & $51.0(96)[100]$ & $51.6(88)[101]$ & - & $69.5(74)[100]$ & $82.6(74)[119]$ \\
\hline & オートクレーブ & - & $58.8(110)[100]$ & $63.0(108)[107]$ & - & $78.5(83)[100]$ & $83.9(76)[107]$ \\
\hline \multirow{4}{*}{ No. 2} & $\overline{\text { 標 }}$ & $53.7(100)[84]$ & $63.6(100)[100]$ & $64.8(100)[102]$ & $92.4(100)[101]$ & $91.5(100)[100]$ & $90.8(100)[99]$ \\
\hline & 父代 & $48.6(91)[95]$ & $51.2(81)[100]$ & $58.9(91)[115]$ & $71.7(78)[94]$ & $76.5(84)[100]$ & $83.0(91)[108]$ \\
\hline & & - & $52.3(82)[100]$ & $56.2(87)[107]$ & - & $77.0(84)[100]$ & $79.5(88)[103]$ \\
\hline & オートクレーブ & - & $60.2(95)[100]$ & $63.2(98)[105]$ & - & $83.5(91)[100]$ & $79.1(87)[95]$ \\
\hline \multirow{2}{*}{ No. 3} & 標 & $51.7(100)[88]$ & $58.9(100)[100]$ & $61.7(100)[105]$ & $87.7(100)[103]$ & $85.5(100)[100]$ & $95.0(100)[111]$ \\
\hline & 気 & $44.5(86)[92]$ & $48.4(82)[100]$ & $53.4(86)[110]$ & $64.0(73)[86]$ & $74.8(87)[100]$ & $80.2(84)[107]$ \\
\hline \multirow{4}{*}{ No. 4} & 標 & $50.7(100)[95]$ & $53.1(100)[100]$ & $62.1(100)[117]$ & $90.1(100)[95]$ & $95.3(100)[100]$ & $96.1(100)[101]$ \\
\hline & & $48.3(95)[93]$ & $51.7(97)[100]$ & $58.1(94)[112]$ & $65.5(73)[92]$ & $71.3(75)[100]$ & $78.0(81)[109]$ \\
\hline & & - & $50.5(95)[100]$ & $55.5(89)[110]$ & - & $67.7(71)[100]$ & $78.5(82)[116]$ \\
\hline & オートクレーブ & - & $58.9(111)[100]$ & $65.0(105)[110]$ & - & $86.1(90)[100]$ & $90.1(94)[105]$ \\
\hline \multirow{4}{*}{ No. 5} & 標 & $48.0(100)[99]$ & $48.4(100)[100]$ & $52.1(100)[108]$ & $87.3(100)[99]$ & $88.0(100)[100]$ & $89.1(100)[101]$ \\
\hline & 父i & $45.6(95)[95]$ & $48.0(99)[100]$ & $56.7(109)[118]$ & $67.9(78)[103]$ & $66.2(75)[100]$ & $75.9(85)[115]$ \\
\hline & & - & $47.4(98)[100]$ & $53.9(103)[114]$ & - & $65.6(75)[100]$ & $75.4(85)[115]$ \\
\hline & オートクレーブ & - & $53.9(111)[100]$ & $56.9(109)[106]$ & - & $73.3(83)[100]$ & $79.1(89)[108]$ \\
\hline
\end{tabular}




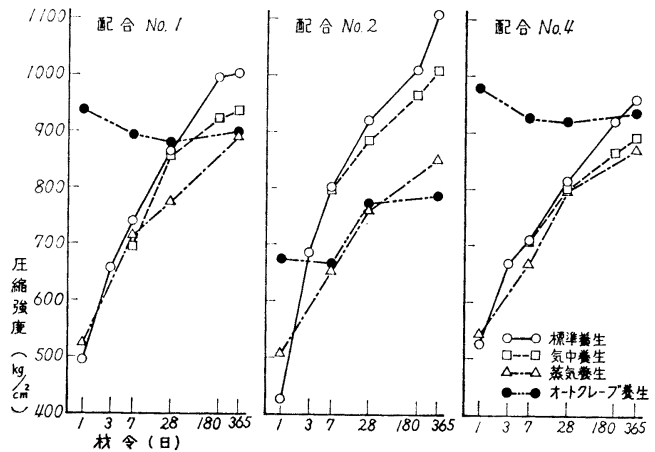

図一2 圧縮強度と材令との関係

引張・曲げ強度を, それぞれ 表一5 および 第一6 亿示 す. 表中の（）は対応する標準養生の強度を 100 とし た場合の相対值であり，〔〕は各養生ごとに材令 28 日 の強度を 100 とした場合の相対値である。

a) 圧縮強度

配合種別 No. 1, No. 2 および No. 4 について, 圧 縮強度と材令との関係を 図一2 に示す.

表一5 および 図一2 によれば,，圧縮強度は材令とと もに増加し, 標準養生を例にとると, 材令 28 日から材 令 1 年にかけて約 $20 \%$ の増加率であるが，オートクレ 一ブ養生においては, 材令 28 日まではむしろ減少気味 に推移し, その後は幾分増加しているがその増加率は非 常に小さい.

養生条件別にみると, 長期材令の圧縮強度増加率は, 配合種別に関倸なく標準盖生がもっとも大きく, 気中養 生, 蒸気養生, オートクレーブ養生の順に小さくなる.

標準養生と蒸気養生とを比べると, 材令 1 日では蒸気 養生の圧縮強度がわずかに大きいが，材令 7 日では標準 養生の方が大きく, この種の高強度コンクリートでは材 令 1 日を問題にする場合以外蒸気養生はあまり有利で はない。

$\mathrm{AE}$ コンクリートでも, 材令 1 年の圧縮強度は材令 28 日のそれより標準養生で約 $150 \mathrm{~kg} / \mathrm{cm}^{2}$, 気中養生で 約 $100 \mathrm{~kg} / \mathrm{cm}^{2}$ 増加しており, 長期の強度増加が十分期 待できる.

b) 引張強度

配合種別 No. 1, No. 2 および No. 4 について, 引 張強度と材令との関係を 図一3 に示す.

表一6 および 図一3によれば，圧縮強度の場合と比心゙ て傾向が幾分異なっており，材令とともに引張強度は増 加しているが, 材令 28 日から材令 1 年までの引張強度 増加率は, 配合種別により若干の差はあるものの養生条 件にあまり関係なく約 $10 \%$ 程度である。

各配合種別の材令ごとの 圧縮強度と引張強度との比 (ぜい度係数) は，普通強度のコンクリートでは 10１3 程度で，一般に 圧縮強度が大きくなるにつれて大とな
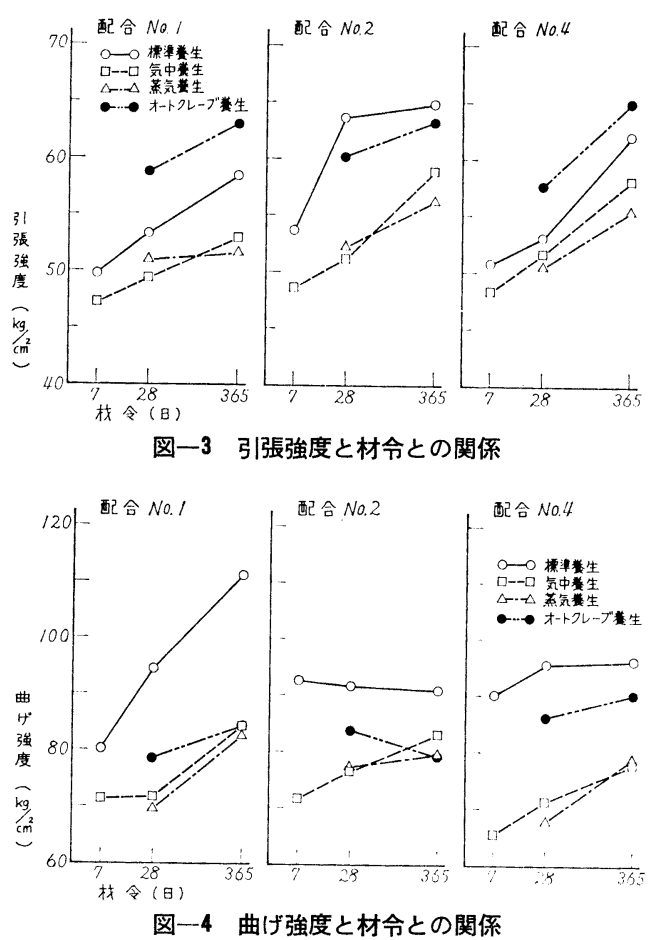

る. 本実験では, 材令 7 日で 14 16, 材令 28 日で 15 ～17, 材令 1 年ではあまり増加せず 15 18 であって, 養生方法ではオートクレーブ養生のものが小さい值を示 している.

c）曲げ強度

配合種別 No. 1, No. 2 および No. 4 について, 曲 げ強度と材令との関係を 図一4 に示す.

表一6 および 図一4によれば, 各配合種別, 養生条件 ごとに材令による曲げ強度增進の傾向は引張強度と類似 している. ただし, 引張強度の場合と異なり, 曲げ強度 はオートクレーブ養生を除いて配合種別 No. 1 が材令 28 日から材令 1 年にかけて 17 19\% の増加率を示し ているが，他の配合種別のものはほとんどが $10 \%$ 以下 で, 特に配合種別 No. 2 が小さい. オートクレーブ養 生では, 材令 28 日から材令 1 年までの曲げ強度増加率 が他の養生のものより小さい傾向が認められる.

配合種別および材令にかかわらず，標準養生したもの が他の養生のものより大きい曲げ強度を示している.

普通強度のコンクリートでは圧縮強度と曲げ強度との 比は 5〜8 であるが, この種の高強度コンクリートでは 8〜12 でほぼ $50 \%$ 大きい数值である. しかし, 材令に よるこの比に顕著な傾向は認められない.

(3) 弾性 係数

表一1 に示す 5 種類の配合種別について 4 種類の養生 を行ったコンクリートの材令 1 年までの静および動弾性 
表一7 静弾性係数および動弾性係数

\begin{tabular}{|c|c|c|c|c|c|c|c|}
\hline \multirow{2}{*}{$\begin{array}{l}\text { 配 命 } \\
\text { 種 }\end{array}$} & \multirow{2}{*}{ 煋生条件 } & \multicolumn{3}{|c|}{ 静弾性:係数 $\left(\times 10^{3}\right)\left(\mathrm{kg} / \mathrm{cm}^{2}\right)$} & \multicolumn{3}{|c|}{ 動弾性係数 $\left(\times 10^{3}\right)\left(\mathrm{kg} / \mathrm{cm}^{2}\right)$} \\
\hline & & $7 \square$ & $28 \mathrm{H}$ & 365 日 & 7 日 & 28 日 & 365 日 \\
\hline \multirow{4}{*}{ No. 1} & & $369(100)[91]$ & $405(100)[100]$ & $434(100)[107]$ & $439(100)[92]$ & $476(100)[100]$ & $501(100)[105]$ \\
\hline & 父 & $350(95)[93]$ & $375(93)[100]$ & $416(96)[111]$ & $418(95)[97]$ & $433(91)[100]$ & $458(91)[106]$ \\
\hline & 蒸 & $339(92)[93]$ & $363(90)[100]$ & $399(92)[110]$ & - & $445(93)[100]$ & $449(90)[101]$ \\
\hline & オートクレーブ & $349(95)[96]$ & $363(90)[100]$ & $381(88)[105]$ & - & $416(87)[100]$ & $420 \dot{(} 84)[101]$ \\
\hline \multirow{4}{*}{ No. 2} & 標 溡 & $447(100)[95]$ & $469(100)[100]$ & $501(100)[107]$ & $486(100)[93]$ & $522(100)[100]$ & $534(100)[102]$ \\
\hline & 父i & $422(94)[92]$ & $458(98)[100]$ & $476(95)[104]$ & $438(90)[96]$ & $458(88)[100]$ & $456(85)[100]$ \\
\hline & & $411(92)[99]$ & $414(88)[100]$ & $418(83)[101]$ & - & $485(93)[100]$ & $478(90)[99]$ \\
\hline & オートクレーブ & $353(79)[86]$ & $412(88)[100]$ & $417(83)[101]$ & - & $459(88)[100]$ & $465(87)[101]$ \\
\hline \multirow{2}{*}{ No. 3} & 標 & $447(100)[93]$ & $482(100)[100]$ & $504(100)[105]$ & $503(100)[96]$ & $523(100)[100]$ & $543(100)[104]$ \\
\hline & 父 & $426(95)[96]$ & $446(93)[100]$ & $466(92)[104]$ & $468(93)[98]$ & $478(91)[100]$ & $504(93)[105]$ \\
\hline \multirow{4}{*}{ No. 4} & 標 & $364(100)[96]$ & $378(100)[100]$ & $433(100)[115]$ & $435(100)[95]$ & $459(100)[100]$ & $498(100)[108]$ \\
\hline & 気 & $343(94)[93]$ & $367(97)[100]$ & $419(97)[114]$ & $406(93)[96]$ & $424(92)[100]$ & $472(95)[1: 11]$ \\
\hline & 蒸 & $345(95)[97]$ & $356(94)[100]$ & $390(90)[110]$ & - & $443(97)[100]$ & $454(91)[102]$ \\
\hline & オートクレーブ & $345(95)[101]$ & $340(90)[100]$ & $354(82)[104]$ & - & $413(90)[100]$ & $424(85)[103]$ \\
\hline \multirow{4}{*}{ No. 5} & 標 & $344(100)[95]$ & $364(100)[100]$ & $410(100)[113]$ & $410(100)[96]$ & $427(100)[100]$ & $456(100)[107]$ \\
\hline & 気 & $336(98)[95]$ & $355(98)[100]$ & $394(96)[111]$ & $392(96)[95]$ & $413(97)[100]$ & $504(111)[122]$ \\
\hline & 蒸 気 & $321(93)[98]$ & $326(90)[100]$ & $372(91)[114]$ & - & $406(95)[100]$ & $423(93)[104]$ \\
\hline & オートクレーブ & $340(99)[103]$ & $330(91)[100]$ & $347(85)[105]$ & - & $386(90)[100]$ & $413(91)[107]$ \\
\hline
\end{tabular}

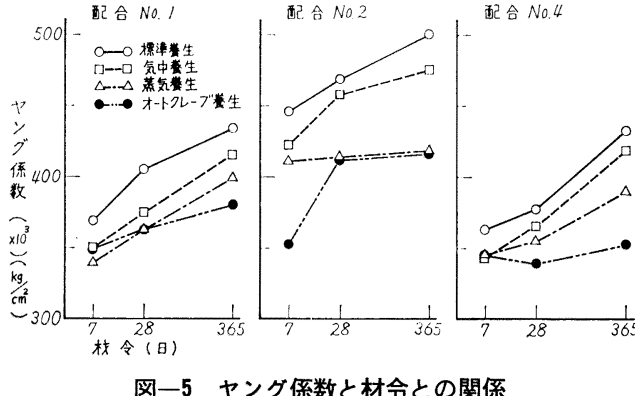

図一5 ヤング係数と材令との関係

係数, ポアソン比に関する試験（ただし，ポアソン比に ついては標準養生のみ）を行った，その結果のうち，静 および動弾性係数の 試験結果を 表一7 に示寸. 表中の （）および〔つの意味は 表一5 と同じである.

a) ヤング係数

ヤング係数は圧縮強度の $1 / 3$ 点の割線ヤング係数とし て求めた.

配合種別 No. 1, No. 2 および No. 4 について, ヤ ング係数と材令との関係を 図一5 に示す.

表一7および 図一5によれば, ヤング係数は各配合種 別とも標準養生の場合が最大で気中養生, 蒸気養生, 才 一トクレーブ養生の順に低下するが，材令 7 日における 差は一般に小さい。

配合種別によるヤング係数を比べると，クリンカー骨 材使用の No. 3 が最大であり, AE コンクリートでは 連行空気量の増加につれて小さい值となっている.

オートクレーブ養生高強度コンクリートのヤング俰数 が小さいことは他にも指摘がされている4) が，本実験に よれば,クリンカー骨材使用のオートクレーブ養生の場 合にヤング係数の長期材令における増加率が小さく, ま
た，他の配合種別においてもオートクレーブ養生の場合 には標準養生の場合に比して全材令にわたってヤング係 数の低下がみられた. 一般に, オートクレーブ養生コン クリートには微細で緻密な水和生成物を生ずるといわれ ているが，ヤング係数が低いことに加えて後述の凍結融 解に対する抵抗性が劣ることから，その組織は必ずしも 緻密であるとは結論できず, 今後の一つの検討課題であ ろう.

材令 28 日から材令 1 年にかけて, 各配合種別ともヤ ング倸数は増加しているが, その増加率はオートクレー ブ養生のものが最も小さく $5 \%$ 以内である.また, 配 合種別では, 空気連行した No. 4, No. 5 のヤング係数 の増加率が大きく,オートクレーブ養生のものを除けば 10〜15\% の伸びである.

クリンカー骨材使用のコンクリートにおいて高いヤン グ係数が得られたことは興味深いが，その理由がクリン カー自体のヤング俰数によるものかクリンカーとセメン トペーストとの結合の良好さによるものかは今後の検討 が必要と思われる.

b） ポアソン比

標準養生を行った 5 種類の配合種別について, 材令 28 日および材令 1 年においてポアソン比を求めた.

圧縮強度の $1 / 3$ 以下の応カレベルにおけるポアソン比 は, 各配合種別とも $0.20 \sim 0.25$ で材令による差は顕著 ではなく, この值は普通強度レベルのコンクリートに比 してやや大きい，また，配合種別による差は明確ではな い.

配合種別 No. 1 の各応カレベルにおける ポアソン比 を図一6 に例示している.

c) 動弾性係数 


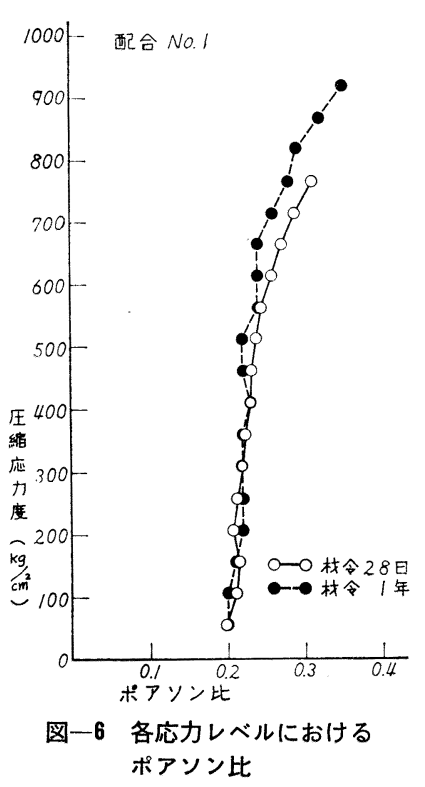

共振法によって求 めた動弾性係数を 表一7 に示す.

表一7によれば, 配合種別および養生 条件が動弹性係数に 及ぼす影響は，ヤン グ係数における場合 と同様である。 た, 材令に伴う動弾 性係数の伸び率は, 一般にヤング俰数の 伸び率よりやや小さ 、傾向がみられる。

動弹性係数に対す るヤング係数の比 は，長期材令になる に従って低下寸る傾 向にあり，クリンカー骨材使用のコンクリートではこの 比が小さいが，その他の配合種別のコンクリートでは材 令 7 日でほぼ 1.2 , 材令 1 年でほぼ $1.1 \sim 1.2$ である.養 生条件によるこの比の差は顕著ではない.

\section{（4）乾燥収縮およびクリープ}

表一1 に示す 5 種類の配合種別の 万ち No. 1 および No. 4 について標準養生およびオートクレーブ養生を行 ったコンクリート供試体 $(10 \times 10 \times 42 \mathrm{~cm})$ を湿度 100 $\%, 80 \%$ および $50 \%$ の 環境条件下（気温梳いずれも $\left.21^{\circ} \mathrm{C}\right)$ 亿静置して, 材令約 250 日までの乾燥収縮およ びクリープによる変形量をフーゲンベルガー型ひずみ計 で測定した。なお，標準養生の供試体は材令 7 日まで $21^{\circ} \mathrm{C}$ の霧室中に, オートクレーブ 養生のものは養生終 了後材令 7 日まで 温度 $21^{\circ} \mathrm{C}$, 湿度 $80 \%$ の恒温恒湿室 中に保管した.

a) 乾燥収縮

材令 7 日における測定值を原点とした材令による乾燥

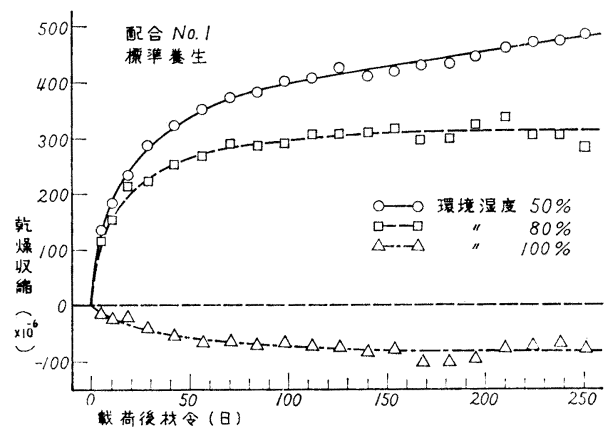

図-7 乾燥 収 縮

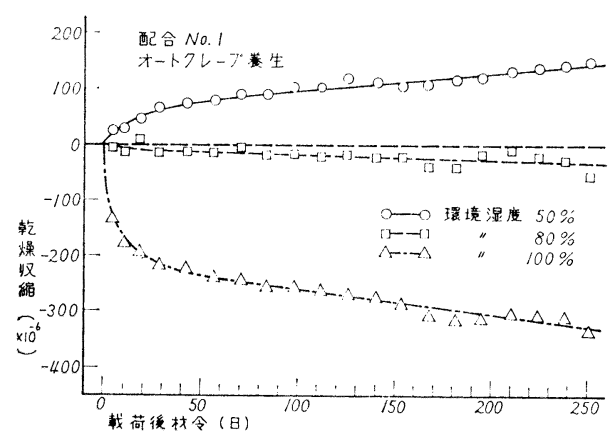

図一8 乾 燥 収 縮

収縮のうち，配合種別 No. 1 を養生別に図示したもの が図一7および 図一8 である.

測定結果からみられる特徴的な諸点を述べれば，同一 配合コンクリートにおいても環境湿度の差によって乾燥 収縮は異なり, 湿度 $100 \%$ ではすべて膨張を示した。

同一配合でも，オートクレーブ養生したコンクリート の乾燥収縮は 標準養生したものと比べるとかなり小さ い.

環境温度，環境湿度 および 養生条件が 同一の場合に は, 配合種別 No. 1 , と No. 4 との間に乾燥収縮の差 は認められない。

b) クリープ

クリープ性状を調べるための供試体として $10 \times 10 \times$ $42 \mathrm{~cm}$ の角柱供試体の 中央に軸方向に $\phi 30 \mathrm{~mm}$ の薄鉄 板製 シースを埋め込み所定の養生ののち $\phi 24 \mathrm{~mm} の$ $\mathrm{PC}$ 鋼棒で破壊強度の $15 \%$ および $30 \%$ の圧縮応力を 導入したものを, 所定の環境湿度の養生室に静置してク リープの測定を行った。なお，応力導入後 28 日目およ び約 230 日目に応力低下補正のため再導入を行った.

クリープの測定結果に応力再導入および乾燥収縮によ る変形量の補正計算を行ってクリープひずみを求めた が，そのうち配合種別 No. 1 についてクリープと材令 との関係を環境湿度別に図示したものが 図一9 11 で ある. また，各材令のクリープ倸数を表一8 に示す.

試験結果によれば, 天然骨材コンクリート No. 1 と

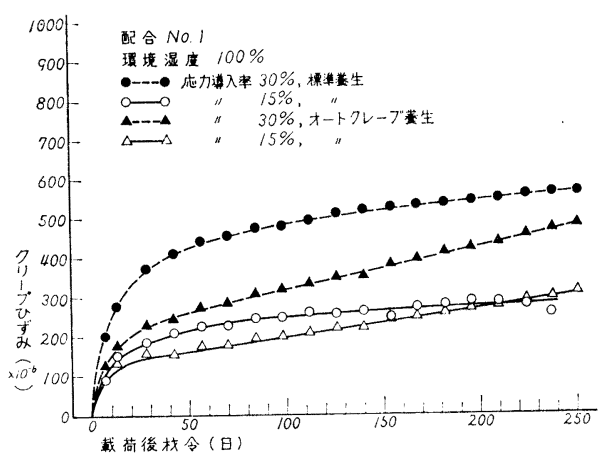

図一9 クリープひずみの経時変化 

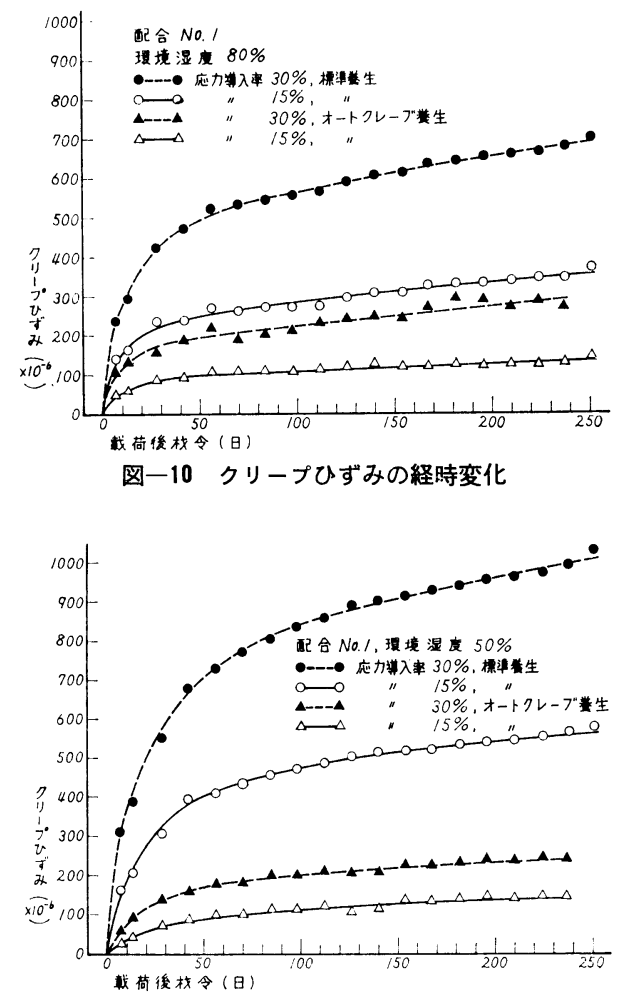

図一11 クリープひずみの経時変化

天然骨材 $\mathrm{AE}$ コンクリートNo. 4 とでは,クリープひ ずみおよびクリープ係数は環境湿度が同一ならばほぼ等 しい，また，養生条件別にみると，同一湿度の下では才 一トクレーブ養生した場合のクリープひずみおよびクリ ープ係数は標準養生の場合より小さく，この傾向は環境 湿度が低いほど顕著である。

同一配合，同一養生条件のコンクリートでも，環境湿 度の変化によってクリープひずみおよびクリープ係数が 大きく異なる. 載荷後材令約 250 日におけるクリープ 係数は, 環境湿度 $100 \%$ で標準養生が約 1.0 , オート クレーブ養生が約 0.8 , $80 \%$ でそれぞれ約 1.4 および 約 $0.4,50 \%$ でそれぞれ 約 2.0 および約 0.4 であっ て，オートクレーブ養生では環境湿度が低くなるとクリ
表一8 クリープ 係 数

\begin{tabular}{|c|c|c|c|c|c|c|c|c|c|}
\hline \multirow{2}{*}{$\begin{array}{c}\text { 環 境 } \\
\text { 湿 度 } \\
(9)\end{array}$} & \multirow{3}{*}{$\begin{array}{c}\text { 載荷後 } \\
\text { 令 } \\
\text { (日) } \\
\text { 入率 }\end{array}$} & \multicolumn{4}{|c|}{ 配合種別 No. 1} & \multicolumn{4}{|c|}{ 配合種別 No. 4} \\
\hline & & \multicolumn{2}{|c|}{ 標準養生 } & \multicolumn{2}{|c|}{$\begin{array}{l}\text { オートクレ } \\
\text { ーブ盖生 }\end{array}$} & \multicolumn{2}{|c|}{ 標準養生 } & \multicolumn{2}{|c|}{$\begin{array}{l}\text { オートクレ } \\
\text { ーブ養生 }\end{array}$} \\
\hline 応力導入率 & & $15 \%$ & $30 \%$ & $15 \%$ & $30 \%$ & $15 \%$ & $30 \%$ & $15 \%$ & 3095 \\
\hline \multirow{9}{*}{100} & 28 & 0.58 & 0.68 & 0.34 & 0.36 & 0.82 & 0.68 & 0.63 & 0.46 \\
\hline & 56 & 0.71 & 0.80 & 0.38 & 0.42 & 0.95 & 0.79 & 0.69 & 0.53 \\
\hline & 84 & 0.77 & 0.86 & 0.43 & 0.48 & 0.99 & 0.83 & 0.75 & 0.58 \\
\hline & 112 & 0.81 & 0.89 & 0.46 & 0.52 & 1.01 & 0.85 & 0.80 & 0.63 \\
\hline & 140 & 0.83 & 0.94 & 0.48 & 0.55 & 1.05 & 0.88 & 0.84 & 0.66 \\
\hline & 168 & 0.85 & 0.97 & 0.54 & 0.61 & 1.11 & 0.91 & 0.90 & 0.71 \\
\hline & 196 & 0.90 & 0.99 & 0.59 & 0.66 & 1.13 & 0.93 & 0.95 & 0.76 \\
\hline & 224 & 0.87 & 1.01 & 0.64 & 0.71 & 1.11 & 0.93 & 1.01 & 0.78 \\
\hline & 251 & 0.86 & 1.02 & 0.68 & 0.75 & 1.12 & 0.94 & 1.07 & 0.83 \\
\hline \multirow{9}{*}{80} & 28 & 0.83 & 0.81 & 0.22 & 0.23 & 0.98 & 0.73 & 0.32 & 0.22 \\
\hline & 56 & 0.95 & 1.00 & 0.28 & 0.32 & 1.22 & 0.93 & 0.35 & 0.26 \\
\hline & 84 & 0.96 & 1.04 & 0.28 & 0.30 & 1.26 & 0.98 & 0.36 & 0.28 \\
\hline & 112 & 0.98 & 1.08 & 0.29 & 0.34 & 1.30 & 1.03 & 0.37 & 0.30 \\
\hline & 140 & 1.09 & 1.16 & 0.33 & 0.37 & 1.38 & 1.10 & 0.40 & 0.32 \\
\hline & 168 & 1.15 & 1.21 & 0.31 & 0.40 & 1.45 & 1.16 & 0.41 & 0.34 \\
\hline & 196 & 1.17 & 1.25 & 0.32 & 0.43 & 1.48 & 1.19 & 0.41 & 0.35 \\
\hline & 224 & 1.22 & 1.27 & 0.33 & 0.43 & 1.54 & 1.20 & 0.42 & 0.37 \\
\hline & 251 & 1.31 & 1.34 & 0.38 & 0.51 & 1.62 & 1.30 & 0.43 & 0.40 \\
\hline \multirow{9}{*}{50} & 28 & 1.18 & 0.99 & 0.20 & 0.22 & 1,12 & 1.00 & 0.19 & 0.19 \\
\hline & 56 & 1.56 & 1.31 & 0.28 & 0.28 & 1.53 & 1.20 & 0.25 & 0.26 \\
\hline & 84 & 1.74 & 1.44 & 0.33 & 0.31 & 1.68 & 1.31 & 0.26 & 0.28 \\
\hline & 112 & 1.85 & 1.54 & 0.35 & 0.33 & 1.78 & 1.39 & 0.26 & 0.29 \\
\hline & 140 & 1.97 & 1.62 & 0.33 & 0.33 & 1.89 & 1.46 & 0.27 & 0.31 \\
\hline & 168 & 1.98 & 1.66 & 0.38 & 0.35 & 1.95 & 1.51 & 0.28 & 0.33 \\
\hline & 196 & 2.06 & 1.71 & 0.42 & 0.38 & 1.99 & 1.54 & 0.30 & 0.35 \\
\hline & 224 & 2.11 & 1.74 & 0.42 & 0.38 & 2.01 & 1.56 & 0.30 & 0.35 \\
\hline & 251 & 2.21 & 1.85 & 0.43 & 0.39 & 2.09 & 1.64 & 0.30 & 0.37 \\
\hline
\end{tabular}

ープ係数が小さくなる現象を示している.

\section{（5）凍結融解に対する抵抗性}

配合種別 No. 1, No. 2, No. 4 および No. 5 の 4 種 類のコンクリートをそれぞれ標準養生およびオートクレ ーブ養生して，これを ASTM C 290 に準じて凍結融解 に対する抵抗性を試験した，その結果を表一9，10 およ び 図-12, 13 に示す.

これらの図表からみられるように，標準養生を行った いずれの配合種別のコンクリートも満足すべき抵抗性を 示しているが, オートクレーブ養生を行った場合には 明らかに抵抗性の劣化を示し，しかも空気連行のない

表一9 30 サイクルごとの動弾性係数百分率

\begin{tabular}{|c|c|c|c|c|c|c|c|c|c|c|c|c|}
\hline \multirow[b]{2}{*}{ 養生:条件 } & \multirow[b]{2}{*}{ 能合種别 } & \multirow{2}{*}{$\begin{array}{c}\text { 試験前心動 } \\
\text { 弾 性係数 } \\
\left(\times 10^{3}\right) \\
\left(\mathrm{kg} / \mathrm{cm}^{2}\right)\end{array}$} & \multicolumn{10}{|c|}{ 動 弾 } \\
\hline & & & 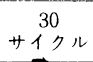 & 60 & 90 & 120 & 150 & 180 & 210 & 240 & 270 & 300 \\
\hline \multirow{4}{*}{ 標淮䍰牛: } & No. 1 & 478 & 99 & 99 & 98 & 99 & 98 & 98 & 98 & 98 & 98 & 97 \\
\hline & No. 2 & 523 & 100 & 101 & 100 & 100 & 101 & 101 & 101 & 101 & 101 & 101 \\
\hline & No. 4 & 458 & 99 & 99 & 99 & 99 & 99 & 99 & 99 & 99 & 99 & 99 \\
\hline & No. 5 & 426 & 100 & 100 & 100 & 100 & 100 & 100 & 100 & 100 & 100 & 100 \\
\hline \multirow{4}{*}{ 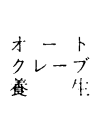 } & No. 1 & 416 & 91 & 88 & 78 & 70 & 61 & 52 & 38 & 測定不能 & - & - \\
\hline & No. 2 & 460 & 92 & 88 & 81 & 68 & 53 & 33 & 測定不能 & - & - & - \\
\hline & No. 4 & 403 & 98 & 96 & 95 & 94 & 94 & 93 & 92 & 91 & 91 & 90 \\
\hline & No. 5 & 369 & 98 & 98 & 96 & 96 & 96 & 95 & 94 & 93 & 92 & 91 \\
\hline
\end{tabular}


表一10 30 サイクルことの重量変化率

\begin{tabular}{|c|c|c|c|c|c|c|c|c|c|c|c|c|}
\hline \multirow[b]{2}{*}{ 㗬生条件 } & \multirow[b]{2}{*}{ 配合種別 } & \multirow{2}{*}{$\begin{array}{c}\text { 試 験 前の } \\
\text { 供試体重量 } \\
(\mathrm{kg})\end{array}$} & \multicolumn{4}{|c|}{ 重 } & 変 & 化 & \multicolumn{2}{|c|}{ (\%) } & & \multirow[b]{2}{*}{300} \\
\hline & & & $\begin{array}{c}30 \\
\text { サイクル }\end{array}$ & 60 & 90 & 120 & 150 & 180 & 210 & 240 & 270 & \\
\hline \multirow{4}{*}{ 標淮䖭生 } & No. 1 & 10.242 & -0.1 & 0 & 0 & -0.1 & 0 & 0 & 0 & 0 & 0 & 0 \\
\hline & No. 2 & 10.440 & 0 & 0 & 0 & 0 & 0 & 0 & 0 & 0 & 0 & 0 \\
\hline & No. 4 & 10.142 & -0.1 & -0.1 & 0 & 0 & -0.1 & 0 & -0.1 & 0 & -0.1 & 0 \\
\hline & No. 5 & 9.964 & 0 & -0.1 & 0 & 0 & 0 & 0 & 0 & 0 & 0 & 0 \\
\hline \multirow{4}{*}{$\begin{array}{l}\text { オート } \\
\text { クレーブ } \\
\text { 根 生 }\end{array}$} & No. 1 & 9.908 & +2.4 & +2.7 & +2.8 & +2.7 & +2.5 & +2.2 & -1.9 & 中 1 : & - & - \\
\hline & No. 2 & 10.099 & +2.2 & +2.6 & +2.6 & +2.8 & +2.8 & +2.8 & +2.6 & +1.6 & 中 止 & - \\
\hline & No. 4 & 9.956 & +2.0 & +2.4 & +2.5 & +2.5 & +2.4 & +2.4 & +2.3 & +2.3 & +2.1 & +2.0 \\
\hline & No. 5 & 9.690 & +2.4 & +2.7 & +2.9 & +2.9 & +2.8 & +2.8 & +2.7 & +2.6 & +2.4 & +2.4 \\
\hline
\end{tabular}

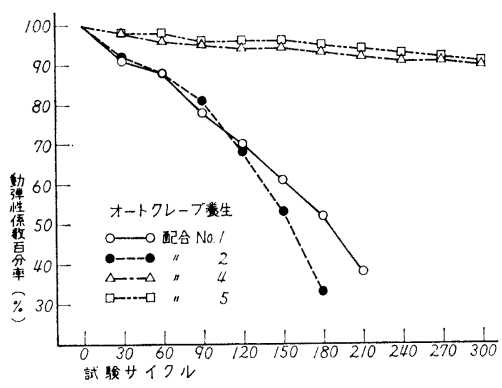

図一12 試験サイクルによる動弾性係数 百分率の変化

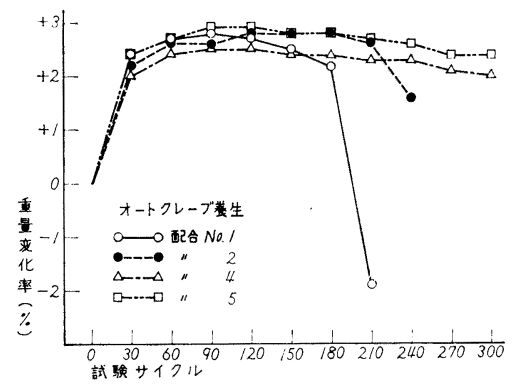

図一13 試験サイクルによる供試体 重贯の変化率

No. 1 および No. 2 は大幅な相対動弾性係数の低下を 示して普通強度のプレーンコンクリートとほぼ同等かそ れ以下の抵抗性と判断される.しかし，2.5 ないし $4 \%$ の空気を連行させた No. 4 および No. 5 は大幅に抵 抗性が改善され, 標準養生のものよりは劣るが相対動弾 性係数の低下は 300 サイクルで約 $10 \%$ であって, ほ ぼ普通強度の $\mathrm{AE}$ コンクリートなみの抵抗性を示して いる.

また，標準養生したコンクリートはいずれも表面スケ ーリングがほとんどないのに対し，オートクレーブ養生 したものはいずれの配合種別のコンクリートも表面がか なりスケーリングされているにもかかわらず，吸水によ り $2 \sim 3 \%$ の重量増加を示している. この吸水による重 量増加は大部分が 30 サイクルまでに起こっており, ま た, 表面のスケーリングは空気量の少ないものほど大で
ある.このことは, ヤング係数のところでも述べたよう に，オートクレーブ養生したコンクリートの組織が必ず しも緻密であるとは限らないことを示唆するものと思わ れる.これは, オートクレーブ養生によって内部構造に 強度までは影響しない程度のきわめて微細なひびわれが 発生し，これによってヤング係数や凍結融解に対する抵 抗性の低下をきたすためと考えられ, 今後の研究が必要 と思われる。

\section{4. 高強度コンクリートのワーカビリチー}

高性能減水剂を使用した高強度コンクリートのワーカ ビリチーは普通強度のコンクリートより経時変化の大き いことが指摘されており ${ }^{8)}$, このことが施工上の問題点 の一つになっている.

この問題に対しては, 現在のところ適切な対策にそし く, 打設時のスランプ低下を見越して減水剂添加量を多 くする方法や，スランプが低下したコンクリートへの減 水剤添加によるリテンパリングの方法がとられている.

ワーカビリチーの経時変化に 影響を及ぼす要因とし て, セメントの種類, 減水剂の種類 - 添加量 - 添加方 法, コンクリートの配合 - 空気量, 温度, 湿度などが考 えられるが,これらのらち, 温度による影響および減水 剂の添加方法について行った試験について述べる.

\section{（1）温度の影響}

普通強度のコンクリートは温度が高くなるとスランプ が低下するが，高性能減水剂を使用した高強度コンクリ 一トにおいて早強セメントを用いた場合に, 温度上昇に つれてスランプが増大するといら逆の現象が認められた ので, この究明のためにモルタルによる基本的な実験を 行い, 次にコンクリートが温度によってそのコンシステ ンシーにどのような影響をらけるかについて試験を行っ た.

a）モルタルのコンシステンシー

試験に使用した 細骨材は鬼怒川産川砂（比重 2.60 , 


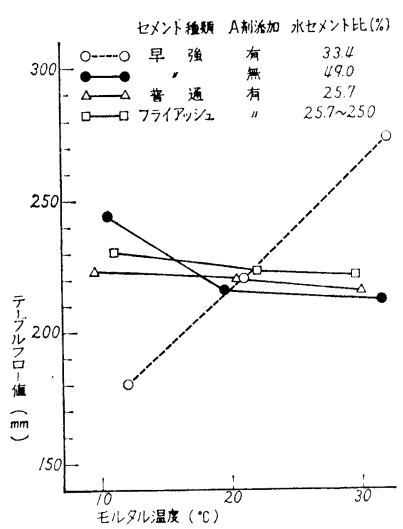

図一14 セメントの種類と $\mathrm{A}$ 剤添 加の有無によるモルタル の流動性比較

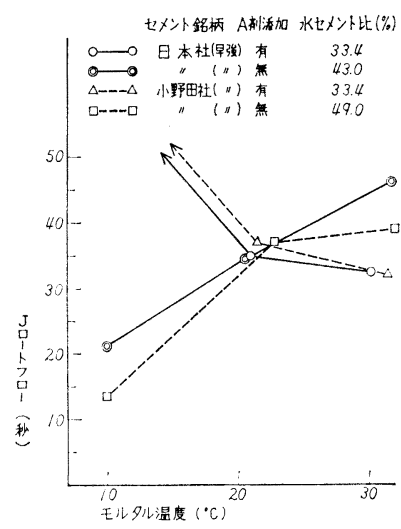

図一15 セメント銘柄によるモル タルの流動性比較
FM 2.73) である. セメント砂比は高強度コンクリート 中のモルタルとほぼ等しい 1.0 とした. 特に断らない 限り減水剤は A 剂でその添加量はセメント重量の 0.75 \%である.

(1) セメントの種類による影響

モルタル温度を $30^{\circ} \mathrm{C}, 20^{\circ} \mathrm{C}, 10^{\circ} \mathrm{C}$ とした場合の七メ ントの種類と $\mathrm{A}$ 剂添加の有無によるモルタルのコンシス テンシーの変化を測定した.

セメントは, 早強セメントと普通セメント（ともに小 野田社製，物性を 表一2 に示す）で，早強セメントに ついてはA剂添加と無添加の 2 種類とし, さらにセメン トの代りにフライアッシュを用いた比較試験も行った.

テーブルフロー值 (JIS R 5201 に準じる) は各配合 ごとに $20^{\circ} \mathrm{C}$ で $220 \mathrm{~mm}$ を基準とし,この水セメント比 を一定として温度変化によるフロ一值の変化を測定し た.

試験結果は, 図一14 に示すように, 早強セメントに A 剂を添加したモルタルのみが温度上昇に比例してフロ 一が大きくなり, 他のモルタルと比べて逆の傾向を示し ている. しかも, この増加率は非常に大きく, $1 \mathrm{deg} の$ 上昇によってフローが $4.7 \mathrm{~mm}$ 大きくなっている.

(2) セメントの銘柄による影響

(1)に述べた現象は早強セメントとA 䨩との組合せの みに認められたので, 次にセメントの銘柄がモルタルの コンシステンシーに及ぼす影響を調べるために $30^{\circ} \mathrm{C}$, $20^{\circ} \mathrm{C}, 10^{\circ} \mathrm{C}$ のモタルについて試験を行った.

セメントは日本社製と小野田社製の早強セメントを使 用した。

流動性の測定方法として J ロートによる流下時間によ ることとし, $20^{\circ} \mathrm{C}$ の モタルの流下時間 35 秒の時の 水セメント比を各配合ごとに一定とした.

試験結果は, 図一15 に示すように, プレーンモルタ ルでは温度降下につれて流下時間が短くなるのに対し,

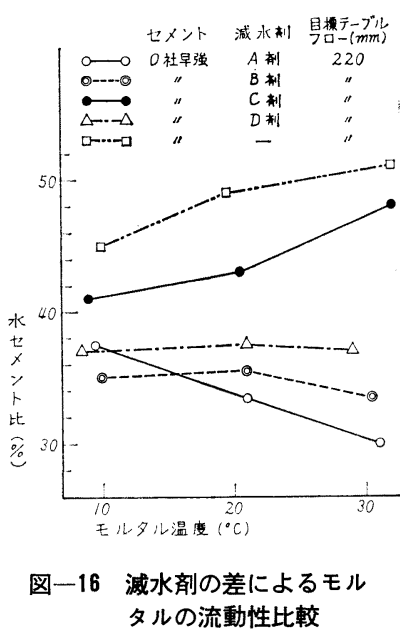

$\mathrm{A}$ 剂添加モルタルでは両銘柄とも同じ傾向を示し, 温度 降下につれて流下時間が長くなり $10^{\circ} \mathrm{C}$ では流下しない 状態であった。

(3) 減水剤の種類による影響

(1),(2)の試験はA剂を添加した場合のものであるが， 他の減水剤を添加したモルタルがどのようなコンシステ ンシーの変化を示すかを調べるため，A剂のほかにナフ タリンスルフォン酸塩のホルマリン縮合物系減水剂 ( $\mathrm{B}$ 剤という), ポリオール 系非空気連行性減水剂 ( C 剂と いら)，高縮合トリアジン系化合物（D㓮という）をそ れぞれ添加した $30^{\circ} \mathrm{C}, 20^{\circ} \mathrm{C}, 10^{\circ} \mathrm{C}$ のモルタルおよび比 較のためのプレーンモルタルについて流動性比較試験を 行った.

セメントは早強セメント（小野田社製）を使用した. 各減水剤の添加量は，B剤はセメント重量の $1.2 \%, \mathrm{C}$ 剤はセメント $100 \mathrm{~kg}$ 当り $250 \mathrm{cc}, \mathrm{D}$ 用はセメント 100 $\mathrm{kg}$ 当り $3000 \mathrm{cc}$ である.

試験は,テーブルフロー值が $220 \mathrm{~mm}$ になるようにし て，水セメント比の変化を調べる方法をとった．

試験結果は, 図一16 に示すように, 温度上昇につれ て C 剂添加モルタル, $\mathrm{D}$ 剂添加モルタル, プレーンモル タルでは水セメント比が不変ないし増大するのに対し, $\mathrm{A}$ 剂添加モルタル, $\mathrm{B}$ 剂添加モルタルでは水セメント比 が減少する傾向，すなわちコンシステンシーがよくなる 傾向を示している.

(4) その他

(1)〜3)にみられる特異な性状をさらに検討するため， 早強セメントに $\mathrm{A}$ 剂を添加して水に賏濁させた $30^{\circ} \mathrm{C}$, $20^{\circ} \mathrm{C}, 5^{\circ} \mathrm{C}$ の分散系についてのセジメントグラフによる 分散性能試験，および(1)で行ったのと同じ材料（セメン トは早強のみ), 配 合による $30^{\circ} \mathrm{C}, 20^{\circ} \mathrm{C}, 10^{\circ} \mathrm{C}$ のル タルについての断熱温度上昇試験を行った.

セジメントグラフによる分散性能試験によれば，一般 


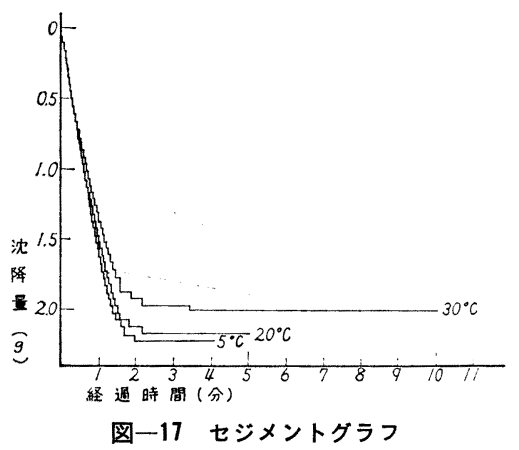

には分散系の温度が高くなれば沈降量が多くなるのに対 し, この 分散系では高温になるにつれて 沈降量は減少 し, しかも $20^{\circ} \mathrm{C}$ から $30^{\circ} \mathrm{C}$ になった場合の沈降量の減 少傾向が顕著である (図一17 参照). 断熱温度上昇試験は，適当な微少熱量計がなかったた 合に見られる特殊性状は，減水剂の分子構造による影響

表一11 コンクリートの配合

\begin{tabular}{|c|c|c|c|c|c|c|c|c|c|c|}
\hline \multirow{2}{*}{$\begin{array}{c}\text { 目標温度 } \\
\left({ }^{\circ} \mathrm{C}\right)\end{array}$} & \multirow{2}{*}{ 配合種別 } & \multirow{2}{*}{$\begin{array}{c}\text { 水セメント比 } \\
(\%)\end{array}$} & \multirow{2}{*}{$\begin{array}{c}\text { 紐尙材流 } \\
(96)\end{array}$} & \multirow{2}{*}{$\begin{array}{l}\text { セメント } \\
\left(\mathrm{kg} / \mathrm{m}^{3}\right)\end{array}$} & \multirow{2}{*}{$\begin{array}{c}\text { 水 } \\
\left(\mathrm{kg} / \mathrm{m}^{3}\right)\end{array}$} & \multicolumn{2}{|c|}{ 混和剂 $(C \times 96)$} & \multirow{2}{*}{$\begin{array}{c}\text { スランプ } \\
(\mathrm{cm})\end{array}$} & \multirow{2}{*}{ 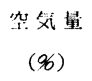 } & \multirow{2}{*}{$\begin{array}{c}\text { コンクリ } \\
\text {-ト温度 } \\
\left({ }^{\circ} \mathrm{C}\right)\end{array}$} \\
\hline & & & & & & 減 水剂 & $\mathrm{AE}$ 剂 & & & \\
\hline \multirow{2}{*}{30} & No. 1 & 33.4 & 36 & 434 & 145 & 0.75 & - & 10.5 & 1.7 & 30.7 \\
\hline & No. 4 & 30.9 & 33 & 485 & 150 & 0.75 & 0.003 & 11.2 & 3.3 & 30.8 \\
\hline \multirow{2}{*}{20} & No. 1 & 33.4 & 31 & 539 & 180 & 0.75 & $\ldots$ & 12.2 & 1.8 & 20.5 \\
\hline & No. 4 & 30.9 & 28 & 582 & 180 & 0.75 & 0.003 & 11.5 & 2.5 & 21.0 \\
\hline \multirow{2}{*}{10} & No. 1 & 33.4 & 31 & 599 & 200 & 0.75 & - & 11.8 & 1.9 & 12.8 \\
\hline & No. 4 & 30.9 & 28 & 680 & 210 & 0.75 & 0.003 & 12.5 & 3.5 & 13.8 \\
\hline
\end{tabular}

表一12 ワーカビリチーの経時変化および強度

\begin{tabular}{|c|c|c|c|c|c|c|c|c|c|c|c|c|}
\hline \multirow{3}{*}{$\begin{array}{c}\text { 槽 } \\
\text { 渵 度 } \\
\left({ }^{\circ} \mathrm{C}\right)\end{array}$} & \multirow{3}{*}{ 配合種別 } & \multirow{3}{*}{ 测定種別 } & \multirow{2}{*}{\multicolumn{5}{|c|}{$\begin{array}{c}\text { 練りまぜ後経 過时間 } \\
\text { (分) }\end{array}$}} & \multicolumn{3}{|c|}{ 仼縮強度 $\left(\mathrm{kg} / \mathrm{cm}^{2}\right)$} & \multirow{2}{*}{\multicolumn{2}{|c|}{$\begin{array}{l}\text { 引张労度 }\left(\mathrm{kg} / \mathrm{cm}^{2}\right) \\
60 \text { 分閒アジテート後採身 }\end{array}$}} \\
\hline & & & & & & & & \multirow{2}{*}{$\begin{array}{l}\text { 直後採集 } \\
\text { 材令28日 }\end{array}$} & \multicolumn{2}{|c|}{60 分間アジテート後採集 } & & \\
\hline & & & 0 & 15 & 30 & 45 & 60 & & 材命 7 日 & 材令28日 & 材令 7 日 & 材命28日 \\
\hline \multirow{8}{*}{30} & \multirow{4}{*}{ No. 1} & スランプ $(\mathrm{cm})$ & 7.5 & 3.2 & 1.3 & - & 0.2 & \multirow{4}{*}{$\begin{array}{c}816 \\
(100)\end{array}$} & \multirow{4}{*}{759} & \multirow{4}{*}{$\begin{array}{l}898 \\
(110)\end{array}$} & \multirow{4}{*}{45.1} & \multirow{4}{*}{52.8} \\
\hline & & $\mathrm{V} F$ 值 $(\mathrm{cm})$ & 5.0 & - & 5.1 & - & 3.9 & & & & & \\
\hline & & 空気 量 (\%) & 1.5 & - & 1.9 & - & 2.1 & & & & & \\
\hline & & 湿 度 $\left({ }^{\circ} \mathrm{C}\right)$ & 30.5 & 29.8 & 29.5 & - & 29.5 & & & & & \\
\hline & \multirow{4}{*}{ No. 4} & スランプ $(\mathrm{cm})$ & 10.8 & 7.4 & 6.5 & 5.0 & 3.7 & \multirow{4}{*}{$\begin{array}{c}903 \\
(100)\end{array}$} & \multirow{4}{*}{833} & \multirow{4}{*}{$\begin{array}{l}952 \\
(105)\end{array}$} & \multirow{4}{*}{50.0} & \multirow{4}{*}{56.9} \\
\hline & & V F 值 $(\mathrm{cm})$ & 7.4 & - & 4.6 & - & 4.6 & & & & & \\
\hline & & 空気 量 (\%) & 2.9 & - & 1.9 & - & 2.2 & & & & & \\
\hline & & 温 度 $\left({ }^{\circ} \mathrm{C}\right)$ & 30.6 & 29.5 & 29.7 & 29.3 & 29.7 & & & & & \\
\hline \multirow{4}{*}{20} & \multirow{4}{*}{ No. 4} & スランプ $(\mathrm{cm})$ & 11.8 & 10.0 & 9.7 & 9.1 & 8.4 & \multirow{4}{*}{$\begin{array}{l}812 \\
(100)\end{array}$} & \multirow{4}{*}{717} & \multirow{4}{*}{$\begin{array}{l}885 \\
(109)\end{array}$} & & \\
\hline & & $\mathrm{VF}$ 値 $(\mathrm{cm})$ & 10.7 & - & 7.3 & - & 6.7 & & & & 108 & 537 \\
\hline & & 空気量(\%) & 1.9 & - & 1.6 & - & 1.5 & & & & 49.8 & 53.7 \\
\hline & & 温 度 $\left({ }^{\circ} \mathrm{C}\right)$ & 21.0 & 20.0 & 20.0 & 20.0 & 20.0 & & & & & \\
\hline & & スランプ $(\mathrm{cm})$ & 12.5 & 10.1 & 9.2 & 8.9 & 7.5 & & & & & . \\
\hline & & $\mathrm{V} F$ 值 $(\mathrm{cm})$ & 7.9 & - & 7.3 & - & 7.1 & 765 & & 840 & & \\
\hline & No. 1 & 空気量(\%) & 1.6 & - & 1.8 & - & 1.7 & $(100)$ & 727 & $(110)$ & 45.5 & 49.2 \\
\hline - & & 温 度 $\left({ }^{\circ} \mathrm{C}\right)$ & 13.0 & 13.0 & 13.1 & 13.1 & 13.2 & & & & & \\
\hline 10 & & スランプ $(\mathrm{cm})$ & 13.2 & 11.6 & 10.4 & 10.1 & 8.5 & & & & & \\
\hline & & $\mathrm{VF}$ 值 $(\mathrm{cm})$ & 12.5 & - & 8.2 & - & 7.0 & 815 & 74 & 891 & 470 & 55.7 \\
\hline & No. 4 & 空気 量 (\%) & 3.0 & - & 1.9 & - & 1.8 & $(100)$ & 741 & (109) & 47.0 & 55.7 \\
\hline & & 温 度 $\left({ }^{\circ} \mathrm{C}\right)$ & 14.0 & 14.0 & 14.2 & 13.5 & 13.5 & & & & & \\
\hline
\end{tabular}

め, 内側寸法 $\phi 12 \times 29 \mathrm{~cm}$ の魔法びんを使用して行っ た.このため, セメントと水が接触してから約 10 分間 は水和熱の測定はできなかったが, 測定結果からは通常 と異なる傾向は認められなかった（図一18 参照).

これらの結果から, 早強セメントにA剤を添加した場 
や拡散二重電位層， 5 電位に関する界面科学的な面から の影響などが考えられ, 今後この方面の研究が望まれ る.

b）コンクリートのワーカビリチー

スランプ $10 \sim 13 \mathrm{~cm}$ 程度で天然骨材使用の $\mathrm{AE}$ 剂添 加と無添加の 2 種類のコンクリートについて, 目標温度 $30^{\circ} \mathrm{C}, 20^{\circ} \mathrm{C}, 10^{\circ} \mathrm{C}$ の下で時間経過につれてワーカビリチ 一がどのような変化をするかを 60 分間経過まで測定し た。

材料として, 早強セメント (小野田社製), 鬼怒川産 玉石砕石（最大寸法 $20 \mathrm{~mm}$ ), 鬼怒川産川砂, 減水剂 $\mathrm{A}$ 剤を使用し， $\mathrm{AE}$ コンクリートにはさらにアニオン系 $\mathrm{AE}$ 剂を使用した.

配合は 表一11 のとおりである.

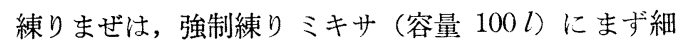
骨材とセメントを投入して 15 秒間空練りしたのちA剂 （および $\mathrm{AE}$ 凰）を混ぜた水を加え，続いて粗骨材を投 入したあと 1 分 30 秒間練りまぜた。練りまぜ終了後は 重力式ミキサにコンクリートを移して $4 \mathrm{rpm}$ (外周速度 $0.175 \mathrm{~m} / \mathrm{sec})$ でアジテートし,所定の時間経過ごとにス ランプ值, VF 值 ( VF 試験器による下がり量), コン クリート温度および空気量を測定した。ささに, 練りま ぜ直後および 60 分経過時に供試体を採取して標準養生 を行い，圧縮強度抢よび引張強度試験を行った。

試験結果は 表一12 のとおりで, コンクリート温度が

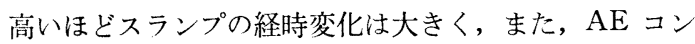
クリートのスランプ低下は $\mathrm{AE}$ 剂無添加コンクリート より小さい。

特異な性状として，A 敵の添加量が同一のコンクリー トでも，温度が上昇し特に $30^{\circ} \mathrm{C}$ にもなるとダイラタン シー的挙動が著しくなり, スランプコーン引き上げ直後 から数秒ないし十数秒間コンクリートの流動がみられ た.この場合のスランプ值の測定時期としては, 配合の 異なる数種類のコンクリートについて測ったスランプの 経時変化の連続性からみて, スランプコーンの引き上げ 直後が適当と思われる.

練りまぜ直後採取のコンクリートの圧縮強度と 60 分 間アジテート後採取のそれとを比較すると, 同一配合で あるにもかかわらず後者の方が大きく, 最大 $9 \%$ 大き
い值となった。

なお，同一配合のコンクリートでも温度が上がると次 第に粗々しくなり，表一11の $30^{\circ} \mathrm{C}$ の闌に見られるよ うに, 同一水セメント比でかつプラスチックでワーカブ ルなコンクリートにするためには, 細骨材率を大きくし なければならない。

\section{（2） 高性能減水剂の添加方法}

同一配合の高強度コンクリートにおいて, 減水剤の添 加方法を変えると, コンクリートの性状に差のあること が認められたので， 2 種類の添加方法について配合， ワ 一カビリチー拉よび強度に関する試験を行った。

高性能減水剂の 添加方法として, 次の 2 種類を用い た.

(1) 同時添加：減水剂（および $\mathrm{AE}$ 剂）を混ぜた水 を細骨材とセメントとを空練りしたものに加え，続 いて粗骨材を投入して 1 分 30 秒間練りまぜる方法

(2) 後添加：細骨材とセメントとを空練りしたものに 水（および $\mathrm{AE}$ 剂）を加え，続いて粗骨材を投入 して 30 秒間練りまぜて最後に減水剤を加えて 1 分 間練りまぜる方法

a ）同時添加と後添加がコンクリートの配合に及ぼす 影響

試験に使用した材料は（1）-b）と同じである.

試験は目標温度 $30^{\circ} \mathrm{C}, 20^{\circ} \mathrm{C}, 10^{\circ} \mathrm{C}$ の場合にスランプ $10 \sim 13 \mathrm{~cm}$ でかつ必要なプラスチシチーを有する高強度 コンクリートの配合が同時添加と後添加とでどのように 異なるかを調べた。

配合種別は，天然骨材使用コンクリート（No. 1) と 天然骨材使用 $\mathrm{AE}$ コンクリート (No. 4) の 2 種類であ る.

配合設計を行った場合の水セメント比, 細骨材率, 材 料単位量などは, 同時添加については 表一11, 後添加 については 表一13 のとおりである.

表一11 および 表一13 からの考察として, 同一温度, 同一配合種別，同一水セメント比でかつ同一スランプと した場合, 後添加の場合には同時添加より単位セメント 量が No. 1 で $54 \sim 60 \mathrm{~kg} / \mathrm{m}^{3}$, No. 4 で $42 \sim 59 \mathrm{~kg} / \mathrm{m}^{3}$ 少なく,また，単位水量がそれぞれ $18 \sim 20 \mathrm{~kg} / \mathrm{m}^{3}, 13 \sim$

表一13 コンクリートの配合（隇水剤後添加）

\begin{tabular}{|c|c|c|c|c|c|c|c|c|c|c|}
\hline \multirow{2}{*}{$\begin{array}{c}\text { 目標温度 } \\
\left({ }^{\circ} \mathrm{C}\right)\end{array}$} & \multirow{2}{*}{ 配合種別 } & \multirow{2}{*}{$\begin{array}{c}\text { 水七メント比 } \\
(.8)\end{array}$} & \multirow{2}{*}{ 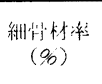 } & \multirow{2}{*}{$\begin{array}{l}\text { セメント } \\
\left(\mathrm{kg} / \mathrm{m}^{3}\right)\end{array}$} & \multirow{2}{*}{$\begin{array}{c}\text { 水 } \\
\left(\mathrm{kg} / \mathrm{m}^{3}\right)\end{array}$} & \multicolumn{2}{|c|}{ 湿和剂 $(C \times \%)$} & \multirow{2}{*}{$\begin{array}{c}\text { スランプ } \\
(\mathrm{cm})\end{array}$} & \multirow{2}{*}{$\begin{array}{c}\text { 空父量 } \\
(\%)\end{array}$} & \multirow{2}{*}{$\begin{array}{c}\text { コンクリ } \\
\text { ート温度 } \\
\left({ }^{\circ} \mathrm{C}\right)\end{array}$} \\
\hline & & & & & & 娍水剂 & $\mathrm{A} E$ 剂 & & & \\
\hline \multirow{2}{*}{30} & No. 1 & 33.4 & 31 & 374 & 125 & 0.75 & - & 7.5 & 1.5 & 30.5 \\
\hline & No. 4 & 30.9 & 33 & 443 & 137 & 0.75 & 0.003 & 10.8 & 2.9 & 30.6 \\
\hline 20 & No. 4 & 30.9 & 28 & 531 & 164 & 0.75 & 0.003 & 11.8 & 1.9 & 21.0 \\
\hline \multirow{2}{*}{10} & No. 1 & 33.4 & 31 & 545 & 182 & 0.75 & - & 12.5 & 1.6 & 13.0 \\
\hline & No. 4 & 30.9 & 28 & 621 & 192 & 0.75 & 0.003 & 13.2 & 3.0 & 14.0 \\
\hline
\end{tabular}


表一14 ワーカビリチーの経時変化および強度（減水剤後添加）

\begin{tabular}{|c|c|c|c|c|c|c|c|c|c|c|c|c|}
\hline \multirow{3}{*}{$\begin{array}{ll}\text { 目 } & \text { 標 } \\
\text { 温 } & \text { 度 } \\
\left({ }^{\circ} \mathrm{C}\right)\end{array}$} & \multirow{3}{*}{ 配合種別 } & \multirow{3}{*}{ 測定種別 } & \multirow{2}{*}{\multicolumn{5}{|c|}{$\begin{array}{c}\text { 練りまぜ後経 過 時間 } \\
\text { (分) }\end{array}$}} & \multicolumn{3}{|c|}{ 玨縮 強度 $\left(\mathrm{kg} / \mathrm{cm}^{2}\right)$} & \multirow{2}{*}{\multicolumn{2}{|c|}{$\frac{\text { 引嗗強度 }\left(\mathrm{kg} / \mathrm{cm}^{2}\right)}{60 \text { 分間アジテート後採集 }}$}} \\
\hline & & & & & & & & \multirow{2}{*}{$\begin{array}{l}\text { 直後採集 } \\
\text { 材令28日 }\end{array}$} & \multicolumn{2}{|c|}{60 分間アジテート後採集 } & & \\
\hline & & & 0 & 15 & 30 & 45 & 60 & & 材令 7 日 & 材命28日 & 材命 7 日 & 材令28日 \\
\hline \multirow{8}{*}{30} & \multirow{4}{*}{ No. 1} & スランプ $(\mathrm{cm})$ & 10.5 & 7.7 & 6.0 & 3.4 & 1.4 & \multirow{4}{*}{$\begin{array}{l}848 \\
(100)\end{array}$} & \multirow{4}{*}{806} & \multirow{4}{*}{$\begin{array}{l}904 \\
(107)\end{array}$} & \multirow{4}{*}{46.0} & \multirow{4}{*}{51.4} \\
\hline & & $\mathrm{V} \mathrm{F}$ 值 $(\mathrm{cm})$ & 9.2 & - & 6.2 & - & 4.4 & & & & & \\
\hline & & 空気 量 (\%) & 1.7 & - & 1.7 & - & 2.1 & & & & & \\
\hline & & 温 度 $\left({ }^{\circ} \mathrm{C}\right)$ & 30.7 & 30.5 & 30.2 & 30.0 & 29.8 & & & & & \\
\hline & \multirow{4}{*}{ No. 4} & スランプ $(\mathrm{cm})$ & 11.2 & 9.5 & 8.2 & 6.9 & 4.9 & \multirow{4}{*}{$\begin{array}{c}892 \\
(100)\end{array}$} & \multirow{4}{*}{817} & \multirow{4}{*}{$\begin{array}{c}934 \\
(105)\end{array}$} & \multirow{4}{*}{51.6} & \multirow{4}{*}{55.9} \\
\hline & & $\mathrm{V} F$ 值 $(\mathrm{cm})$ & 8.1 & - & 6.5 & - & 5.9 & & & & & \\
\hline & & 空気 量 (\%) & 3.3 & - & 2.3 & - & 2.4 & & & & & \\
\hline & & 温 度 $\left({ }^{\circ} \mathrm{C}\right)$ & 30.8 & 30.3 & 30.6 & 30.5 & 30.5 & & & & & \\
\hline \multirow{8}{*}{20} & \multirow{4}{*}{ No. 1} & スランプ $(\mathrm{cm})$ & 12.2 & 9.8 & 9.5 & 7.0 & 7.0 & \multirow{4}{*}{$\begin{array}{c}785 \\
(100)\end{array}$} & \multirow{4}{*}{637} & \multirow{4}{*}{$\begin{array}{l}804 \\
(102)\end{array}$} & \multirow{4}{*}{46.9} & \multirow{4}{*}{49.9} \\
\hline & & $\mathrm{V} \mathrm{F}$ 值 $(\mathrm{cm})$ & 8.9 & - & 8.3 & - & 6.9 & & & & & \\
\hline & & 空気 量 (\%) & 1.8 & - & 2.0 & - & 2.1 & & & & & \\
\hline & & 温 度 $\left({ }^{\circ} \mathrm{C}\right)$ & 20.5 & 20.7 & 21.0 & 21.0 & 21.0 & & & & & \\
\hline & \multirow{4}{*}{ No. 4} & スランプ $(\mathrm{cm})$ & 11.5 & & 9.8 & 6.6 & 6.0 & & & & & \\
\hline & & $\mathrm{V} F$ 值 $(\mathrm{cm})$ & 11.2 & - & 7.5 & - & 7.0 & & & 834 & & \\
\hline & & 空気最 $(\%)$ & 2.5 & - & 2.1 & - & 2.0 & $(100)$ & 714 & ( 99$)$ & 48.6 & 53.6 \\
\hline & & 温 度 $\left({ }^{\circ} \mathrm{C}\right)$ & 21.0 & 21.0 & 21.2 & 22.0 & 21.0 & & & & & \\
\hline & & スランプ $(\mathrm{cm})$ & 11.8 & 9.5 & 7.9 & 6.9 & 7.0 & & & & & \\
\hline & & $\mathrm{V} \mathrm{F}$ 值 $(\mathrm{cm})$ & 11.7 & - & 7.9 & - & 7.6 & 770 & & 840 & & \\
\hline & No. 1 & 空父䭪 $(\%)$ & 1.9 & -- & 2.0 & - & 2.0 & $(100)$ & 722 & (109) & 41.8 & 48.3 \\
\hline 10 & & 温 度 $\left({ }^{\circ} \mathrm{C}\right)$ & 12.8 & 13.1 & 13.3 & 13.0 & 13.0 & & & & & \\
\hline 10 & & スランプ $(\mathrm{cm})$ & 12.5 & 9.9 & 10.0 & 9.4 & 9.7 & & & & & \\
\hline & & $\mathrm{V} F$ 値 $(\mathrm{cm})$ & 16.0 & - & 9.3 & - & 8.8 & 756 & & 799 & & \\
\hline & No. 4 & 究気量 (\%) & 3.5 & - & 2.6 & - & 2.2 & $(100)$ & 696 & (106) & 46.0 & 47.8 \\
\hline & & 沿度 $\left({ }^{\circ} \mathrm{C}\right)$ & 13.8 & 14.2 & 14.2 & 13.5 & 13.5 & & & & & \\
\hline
\end{tabular}

$18 \mathrm{~kg} / \mathrm{m}^{3}$ 少なくなっており,この減少量は単位セメント 量, 単位水量のおよそ $10 \%$ にあたる大きい量である. この現象の理由は明らかではないが，七メント粒子の表 面の活性に対して水が先にある程度吸着されるため, 結 果的に減水剤を多量添加したのと同様な効果を発揮して 流動性が良くなるためではないかと考えられる.

また，コンクリート温度の変化が配合に及ぼす影響 は, 同一配合種別 (同一水セメント比) のコンクリート では高温になるに従って単位セメント量, 単位水量とも 大きく減少し，その減少量は同時添加，後添加ともほぼ 同程度で, $1 \mathrm{deg}$ の上昇についてセメント量は 9.7〜 $11.5 \mathrm{~kg} / \mathrm{m}^{3}$, 水量は $3.2 \sim 3.5 \mathrm{~kg} / \mathrm{m}^{3}$ である.

b） 同時添加と後添加がコンクリートのワーカビリチ

\section{一および強度に及ぼす影響}

同一配合種別（同一水セメント比）の高強度コンクリ 一トにおいて, 同一スランプ, 同程度のプラスチシチー でも，a）に述べたように，減水剂の添加方法が単位セ メント量, 単位水量にかなり影響を及ぼすことが分かっ た.このことから, 配合設計上の条件（水セメント比, スランプ）を一定にした場合に, 減水剂の同時添加と後 添加がワーカビリチーの経時変化および強度にどのよう な影響を及ぼすかを, 目標温度 $30^{\circ} \mathrm{C}, 20^{\circ} \mathrm{C}, 10^{\circ} \mathrm{C}$ の下 で試験を行った。

材料および配合は a) の場合と同じである. 所定の練りまぜ後，(1)-b)「コンクリートのワーカビ リチー」で行ったのと同じ測定および供試体の作製，養 生, 強度試験を行った。

試験結果は, 同時添加の場合は 表一12 に，後添加の 場合は 表一14 に示すとおりである.

これらの表を比較すると，同一配合のコンクリートに 減水剤を同時添加した場合と後添加した場合とでは，い ずれもワーカビリチーは時間とともに低下し，その傾向 浊者ともほとんど同じである. また, 温度が高いコン クリートの時閒経過によるスランプの低下は, 低温のも のより幾分大きい.

強度については, 同時添加のコンクリートと後添加の コンクリートとでは，コンクリート温度または供試体採 取時期（練りまぜ直後と 60 分間アジテート後）による 圧縮強度の差はほとんど認められない. また, 同時添加 あるいは後添加の場合とも, 練りまぜ值後に採取したコ ンクリートの 28 日圧縮強度に対して 60 分間アジテー 卜後採取したものの方がコンクリート温度にかかわらず 大きく, その増大率は同時添加の場合に 0 9\% 程度, 後添加の場合に 5〜10\% 程度である.

\section{5. 結 論}

混和剤として多環アロマスルフォン酸塩系減水剤を使 
用し，一部実験にアニオン系 $\mathrm{AE}$ 剂をも添加した高強 度コンクリートについて, 骨材として天然骨材のほかク リンカー骨材を用いた数種類の配合種別のコンクリート の養生方法を変化させた場合の硬化したコンクリートの 諸性状，ならびに天然骨材を用いたコンクリートの温度 による影響および減水剤の添加方法の差による影響，に つき試験した結果を要約すると，次のとおりである.

（1）高性能減水剤の使用により，スランプ 10〜13 $\mathrm{cm}$ のコンクリートにおいて水セメント比を $40 \%$ 以下 にでき, 材令 28 日で $800 \mathrm{~kg} / \mathrm{cm}^{2}$ 以上の圧縮強度が得 られ, しかも圧縮強度はセメント水比とほぼ直線関係で 近似できる。

（2） 4 種類の養生条件のもとで, コンクリートの強 度は材令とともに増加する。しかし，その増加率は異な り, 材令 28 日から材令 1 年にいたる間の圧縮強度の増 加率は，標準養生の場合には約 $20 \%$ であるが，オート クレーブ養生の場合には非常に小さい.

また, 引張強度, 曲げ強度の増加率は圧縮強度のもの より小さく, ぜい度係数, すなわち圧縮強度と引張強度 との比は高強度コンクリートの場合 14〜18 であり, 普 通強度コンクリートの場合より大である.

（3）クリンカー骨材コンクリートでは, 同一圧縮強 度および同一ワーカビリチーを得るための単位水量, 単 位セメント量は, 天然骨材コンクリートに比して小さく なる. 一方, $\mathrm{AE}$ コンクリートでは単位水量, 単位セメ ント量が大となる.

（4）ヤング係数は, 養生条件については標準養生の 場合がもっとも大きいが, 天然骨材コンクリートの材令 28 日で $405 \times 10^{3} \mathrm{~kg} / \mathrm{cm}^{2}$, 材令 1 年で $434 \times 10^{3} \mathrm{~kg} / \mathrm{cm}^{2}$ で圧縮強度の伸びに対してヤング係数の伸びは小さい. しかし，クリンカー骨材コンクリートでは，材令 1 年で $501 \times 10^{3} \mathrm{~kg} / \mathrm{cm}^{2}$ の高い值が得られた.

オートクレーブ養生を行った場合のヤング係数は, 他 の養生に比べて特に長期材令において低く, 材令による 増進があまり見られない.

（5）乾燥収縮, クリープに関しては, 天然骨材コン

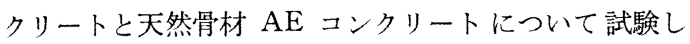
た結果，コンクリート配合の差による影響はほとんど認 められないが, コンクリートの養生条件, 環境湿度が大 きく影響する。

養生条件がクリープに及ぼす影響としては, オートク レーブ養生したコンクリートのクリープひずみおよびク リープ係数は，標準養生のものより小さい．この傾向は 環境湿度が小さくなるにつれて顕著になる。

環境湿度が変化すると, 同一配合, 同一養生条件でも クリープひずみおよびクリープ係数は大きく異なり，環 境湿度が高くなるにつれて標準養生したコンクリートで
はクリープひずみおよびクリープ係数は小さくなり，才 ートクレーブ養生コンクリートでは逆に大きくなる傾向 を示すが，いずれも普通強度のコンクリートよりもかな り小さい值である.

（6）凍結融解に対する抵抗性試験の結果, オートク レーブ養生したコンクリートは抵抗性の劣化を示し, 普 通強度のプレーンコンクリートと同程度またはそれ以下 しかなく, 特に空気連行のないコンクリートの抵抗性は 大幅に低下する. 一方, 空気連行のあるオートクレーブ 養生のコンクリートおよび空気連行の有無にかかわらず 標準養生のコンクリートの抵抗性は満足すべきもので, 普通強度の $\mathrm{AE}$ コンクリートと同等ないしはそれ以上 の抵抗性を有している.

（7）コンクリートのワーカビリチーは時間経過につ れて低下し, その傾向は普通強度のコンクリートより著 しい.

早強セメントおよび天然骨材を使用した空気連行のあ るコンクリートと無いコンクリートについての試験によ れば，いずれも高温になるほどスランプの経時変化は大 きく, かつ $\mathrm{AE}$ コンクリートより $\mathrm{AE}$ 用無添加のコン クリートの方がスランプの経時変化は大きい.

特異な性状として, コンクリートが $30^{\circ} \mathrm{C}$ 程度以上の 高温になるとダイラタンシー的挙動が著しくなるが, こ の時のスランプ值はスランプューン引き上げ直後の值を とるのが適当と思われる.

（８）多環アロマスルフォン酸塩系減水剤またはナフ タリンスルフォン酸塩のホルマリン縮合物系減水剂と早 強セメントを用いたモルタルについての試験によれば, 通常のモルタルとは逆に, 温度の上昇につれてコンシス テンシーが良くなる性質を有することが分かった. その 原因について調べたが水和熱の異常発生も認められず, 減水剂の分子構造からくるものか拡散二重電位層や 位に関する界面科学的な面からの影響と考えられる.

（9）コンクリート練りまぜ時の高性能減水剂の同時 添加と後添加とでは, コンクリートの配合およびワーカ ビリチーは大きな影響をらけ, 後添加の場合には同時添 加と比べて同一スランプとするための単位水量および単 位セメント量は大幅に減少する.

(10) 練りまぜ後 60 分間アジテートしてから採取し たコンクリートの 28 日圧縮強度は, 配合種別, 減水剂 添加方法, 温度にかかわらず, 練りまぜ㨁後に採取した ものより大きく, 最大 $10 \%$ 大きい值を示した.

以上述べたように, 本研究の結果から高強度コンクリ 一トに関して多くの特性が明らかとなった．この種のコ ンクリートによる構造物の設計施工は今後子えることと 思われるが，このコンクリートは本質的には従来から用 いられている普通強度のコンクリートと異なるものでは 
ないので, 高強度コンクリートによる構造物の設計施工 にあたっては, 本論文で指摘した諸点について配慮し， その特性を知って使用すれば，十分に目的を達すること ができる。

謝 辞 : 本研究を進めるにあたり, 終始ご懇篤なご指 導を賜わった京都大学岡田清教授, 同小柳 洽助教授掞 よび試験にあたり多くの援助と便宜を与えていただいた 関係の方々に厚く謝意を表します.

本論文は, 京都大学審査学位論文である.

\section{参 考 献}

1）近藤時夫・小柳 洽・児玉和巳 : 高強度コンクリートの諸 特性と耐久性について, 材料, Vol. 24, No. 260, pp. $432 \sim 440,1975$ 年 5 月.

2）児玉和巳・福島直昭・御所窪邦男: 高強度用減水剂につ いて, 材料, Vol. 22, No. 232, pp. 11 17, 1973 年 1 月.
3）西岡思郎・憍本正幸: : 高性能減水剂の利用に閶与る試験, セメント・コンクリート, No. 311, pp. 19２6, 1973 年 1 月.

4) 六車 熙・田中進三:高強度:エンクリートの力学的特性に ついて, セメント技術年報 27 巻, pp. $243 \sim 247,1973$ 年.

5）吉田弥智・赤村：登・飯坂武男：高性能混和剂に関する基 礎的研究，セメント技術年叔 27 巻， pp. 153〜157, 1973 年.

6) コンクリート橋の長大化に闒する调査研究報告書, 同资 料, プレストレストコンクリート技術永会, 炤和 45 年度, 46 年度, 47 年度.

7) Abrams, D.A. : Design of Concrete Mixture, Structural Materials Research Lab., Lewis Institute, Bulletin 1, Chicago, 1919.

8）たとえば, 東京工業大学長滝研究公 : 高強度コンクリー 卜に関する実験研究（参考文献 7) 0昭和 46 年度報告書 資料に揭載), 1972 年 4 月.

(1976.9.18 · 受付) 